\title{
Integrated Support Strategies for Promotion of Students' Retention and Achievement During First Years of College
}

\author{
Beverlyn Grace-Odeleye, $\mathrm{PhD}$ \\ Correspondence: Dr. Beverlyn Grace-Odeleye, Department of Academic Enrichment and Learning, East Stroudsburg \\ University of Pennsylvania, 200 Prospect Street, East Stroudsburg, PA 18301, USA. E-mail: beverlyn@esu.edu
}

Received: September 9, 2019

Accepted: October 20, 2019 Online Published: February 18, 2020

doi:10.11114/ijce.v3i1.4725

URL: https://doi.org/10.11114/ijce.v3i1.4725

\begin{abstract}
Persistence and increased retention is a major focus in higher educational administration. The first-years of transition to college is a multi-dimensional new academic experience, noncognitive, and social challenges, often a disorienting period which can lead to academic difficulties. This review examines the literature for strategies, institutional policies and approaches for effective retention and first-year students' success programs supported by evidence that contributes to satisfactory student performance, persistence and retention in post-secondary education. This review aim to develop a knowledgeable perspective on higher educational integrated and collaborative guiding principles for refining student learning and success efforts for improvements in student performance, persistence, and retention. The implications for practice are discussed and recommendations for of institution-wide collaborative critical strategies supported by data proven effective for the promotion, retention and success of first-year students' success is provided.
\end{abstract}

Keywords: retention initiatives, college success, institutional policies, persistence, academic and students affairs

\section{Introduction}

There is a considerable leakage in the college educational pipeline. The National Center for Education Statistics (2018) and National Student Clearinghouse Center (2018) estimated about 60 percent of students started bachelor's degree at 4year institutions in 2010 completed that degree by end of 2016, with $33 \%$ not returning to complete college. Retention rates have remained virtually stagnant since the mid-1990's at two-year and four-year institutions. The first years of college continues to be the most critical and greatest vulnerable period for attrition with more than half of all withdrawals from college occur during the first year. The national attrition rate for first-years students is higher than $25 \%$ at four-year institutions, and almost 50\% at two-year institutions (McFarland, Hussar, Wang, Zhang, et al., 2018). Retention and persistence to degree attainment is a complicated process with mostly a two-way relationship: the student and the educational institutional available academic and social support programs to enhance students persistence. From the students' readiness perspective, high school academic achievement, socioeconomic status, gender, commitment to earning a degree, and their personal academic and social commitments and involvement influence persistence and degree attainment (Tinto, 1993). These factors are mostly outside the institutional context, yet college institutional perspectives and commitments play pivotal roles in students persistence and outcomes to mitigate the high attrition rate.

Focus on student retention, success and graduation rates is increasingly used by State and Federal funding agencies, policy makers, and institutions as an index of validation of the accomplishment of educational institutions mission to educate and prepare students for life-long goals and career ambitions (Kim, Newton, Downey, \& Benton, 2010; Engel, 2015), and by students applicants in their college selection processes when examining institutional quality (Noel-Levitz, 2008). High attrition rate has societal and personal consequences. According to an American Institutes for Research Report (2011), college dropouts lose about $\$ 4.5$ billion in missed personal earnings, in addition to the lost annual federal and state income tax revenue. For the individual, the effects of dropping out include wasted investments, family conflicts, limited career options and opportunities, decreased earning potential, and high personal costs to students and families since much of the debts is financed by student and federal taxpayers (Casselman, 2012). In addition to being a critical year for student retention, first year of college is a critical period for student learning and cognitive development as more cognitive growth and learning happens during the first year than other successive college years. The first year, therefore present a "window of opportunity" for promotion of students' learning that would be missed if colleges do not provide and a greater proportion up-front their best learning resources and support interventional programs during this critical time (MacGregor, 1991, 2000; Greenfield, Keup, \& Gardner, 2013) and the most efficient way to boost graduation rates is to reduce the 
first-to-second-year attrition rate (Levitz, Noel, \& Richter, 1999). Other reports have suggested the cognitive, academic involvement in the first-year lay the groundwork for the entire college experience (Grave, 2011). Expectedly, higher educational institutions should organize its administrative and support services to preventatively deliver interventions and academic support programs that increase academic and social engagements during this initial year as these programs exert beneficial effects beyond the first years of college (College Board, 2009). To address the problems of early attrition, some studies have offered general recommendations including students increasing students' engage in educationally purposeful activities that persistence, and achievement of their educational goals. Additionally, these report concluded that educational institutions that subscribe to a talent development philosophy, and create a student-centered culture are better positioned to help students attain their educational objectives (Nelson \& Schreiner, 2013; Strahan \& Crede 2015; Havlik, Pulliam, Malott \& Steen, 2017; US Department of Education, 2017).

This review focus on policies and practice areas higher education institutions can influence and provide support systems that mitigate the high attrition rate that occurs during the first years of higher education. The role of institutions policies and practices that impact on increased persistence and graduation though critical, yet little is known about how integrated collaborative institutions programs and efforts synergistically boost measures of student success. To make retention efforts more effective, institutions need empirically grounded information that is contextually specific on how to better organize, integrate and coordinate institutional programs, and on student-institution interactions that contribute to increase persistence and retention. This review focus on the major institutional conditions - policies, programs, practices, and collaborative programing that offers practical approaches and interventions that impact on student's success. Additionally, these kinds of benchmarked information are useful for institutions assessment of their own efforts, and for planning new and refining established programs.

\section{Justification for a Comprehensive and Integrative Academic Support During the First Years of College}

According to an ACT publication (2005), only 22 percent tested students are ready for college-level work in deficit areas of English, math, and science with too many students discontinuing beyond the first year of college. Retention, especially progression to the second-year has gained great attention along with the emergence of developmental, academic, and social and other interventional support strategies to assist persistence and lower attrition in this most vulnerable year for underprepared students (Grace-Odeleye, 2015; Gershenfeld, Hood \& Zhan, 2016; US Department of Education, 2017; Mazlan, Aziz, Mohamed, Ismail, \& Shah, 2017). These findings collectively suggests institutions should deliver academic support proactively and intrusively during the first years of college to intercept potentially high first-year attrition, rather than reactive responses to student difficulties after they occur (Haktanir, Waatson, \& Streeter, et al. 2018; Kim, Lim \&, Stewart, 2015). Additionally, these support programs serve to lay the groundwork for self-efficacy and learning on which cumulative gains in learning and development during subsequent years are built on. Therefore, educational and social intervention programs that serve to increase the academic achievement of immediate outcomes such as first-year academic performance and retention has the potential for promoting the realization of intermediate and long-term successful outcomes (Raab \& Adam 2005).

Although no universal templates or format exists on the conduct of first-year-programs, several studies have posited key principles that must be a part of all first-year experience programs. This review explores the first-year experience specific organizational strategies, based on data research, for improving the first-year experience models required for persistence and improved retention. Multiple theories, approaches and models have been proposed for college-wide support professionals and practitioners bringing to life theoretical knowledge to enhance the development and learning. One of these models is the psychosocial and social identity development, and the cognitive development theory that merges the art of practice in multidimensional holistic ways. These theoriesintertwine the science of theory with the art of practice in multidimensional holistic ways that emphasize the psychosocial, social identity development, and cognitive developmental dimensions (Branch, Hart-Steffes, \& Wilson, 2019; Patton, Renn, Guido, \& Quaye, 2016; Wolverton \& Dee, 2010). This review, support and build on the Holistic Student Development Theories which focus on campus-wide integrative and collaborative programs strategies, policies, practices, and services that can be harnessed for promotion of students retention. In addition, it provides a much-needed practical guide for intertwining the science of theory with the art of practice that facilitates student success (Strange \& Banning 2015; Strayhorn, 2016). The following forms of collaborative strategies are illustrative and supported by a substantial body of evidence.

\section{Students' Collaboration or Peer Collaboration}

Effective academic support programs for first-year students make the most of the power of peers interactions between students known to have a positive impact on student retention (Altermatt, 2016). Intentional fostering collaboration among students represents an effective strategy for retention promotion and reduced attrition because it promotes students' social integration among peers and into the college community (Woosley, Sherry \& Shepler, 2011). Peer collaboration advance students' cognitive development, stimulate critical thinking skills and enhance better academic and psychological 
judgement (Burton, Chester, Xenos \& Elgar 2013, De Backer, Van Keer \& Valcke, 2012), all of which are major contributors to enhanced self-perception, confidence and self -efficacy.

\section{Classroom Instructors and Academic-Support Services Collaboration}

Students' academic success depend largely on quality of curriculum, classroom instructions, effectiveness of crucial outof-class services learning assistance, and academic advisement services. Support programs that connects students with learning specialists and academic advisors provide timely and seamless support for at-risk first-year students with ineffective learning strategies and or deficits of educational goals, and lack sense of self-direction to function academically. Additionally, instructional faculty and academic support-service professionals interactions and collaboration result in combinatorial effects on student learning and development, thereby exacerbating the educational impact of the support services (Zhang, Gossett, Simpson \& Davis 2017; Drake, 2011a). National evaluations of educational service programs suggests their success centers upon the higher degree of participants self-perception of students see themselves as fundamental to institutional life (Tinto, 1993; Deangelo, 2014; Kim \& Sax, 2017) ). Collaboration between faculty and academic-support specialists empower support programs to become more "mainstreamed," thereby increasing the likelihood these programs are not viewed as "supplemental" but vital to the college's day-to-day operations and critical to the college mission to enhance persistence and retention.

\section{Academic Divisions and Student Affairs Collaboration}

Good Practice in Student Affairs, at the minimum, include the following elements: engage students in active learning; support students' development of coherent values and ethical standards; set and communicate high expectations for student learning; use systematic data collection and analysis to improve students and institutional performance; use resources effectively to achieve institutional missions and goals; build educational partnerships that advance student learning, and a supportive and inclusive community. Intrinsic in each of the "good practice" require a close Students Affairs, and academic divisions and faculty collaborations. Students' academic success depends largely on cognitive factors, social adjustment to the college environment, emotional stability, personal wellness, adaptions to the academic rigors that foster performance in their course work - which contribute to retention. A comprehensive academic support program for first-year students' therefore need to focus on the students holistic support and development that address the full range of academic and non-academic factors that support students' success. Seamless connections between faculty and student affairs is critical to student development as both play major roles in transition and orienting students to campus, and advising students in various aspects of personal and professional growth. Research shows that integrated academic support programs with features that target different students' needs are more effective than single-focused programs restricted to the academic or cognitive domain (Roueche \& Roueche, 1993). Empirical data studies has also shown student retention is more effectively promoted at institutions where campus culture is integrated more closely and with collaborative activities between academic and student affairs (Kuh, Schuh, Whitt, \& Associates, 1991; Oseguera \& Rhee, 2009) and college counselors (Haktanir, \& Streeter et al, 2018). Other benefits of bridging the gap between Student and Academic Affairs include the seamless connection between in- and outside classroom experience, co-curricular experience that enhance and complement the academic curriculum, students' increased use of available resources, support for academic and personal success, and increased satisfaction with the overall college experience (Strahan \& Crede, 2015).

\section{Collaboration Among Students through Peer Support Programs}

The influence of peers in the promotion of student learning has been highlighted by extensive reviews of higher education research on teaching and learning that concluded students teaching other students is the most effective methods of teaching after well-developed learning goals and content by a faculty (Hammond, Bithel, Jones \& Bidgood, 2010; Ho, 2006). In addition to these cognitive benefits, peer collaboration also support development of key social skills essential for success in college and post-college careers (Mellado, Valdebenito \& Aravena, 2017).

\section{Peer Tutoring}

Peer tutoring pairs high-performing students in the subject area to tutor lower-performing students in a classroom format or common venue outside of classrooms. These peer tutors are selected for their high academic performances and social skills and typically receive specialized training under the aegis of the college's educational support services including Learning Assistance Center or Academic Enrichment. Higher education research on peer teaching/learning consistently shows both the peer learner and the peer-teacher experience significant gains in learning from the collaborative interactions (Cottam, Menzel, \& Greenblatt, 2011; Kiyama \& Luca, 2016). Additionally, the peer-tutoring students display deeper levels of understanding of the concepts of the subjects they teach to other students (Benware \& Deci, 1984) and achieve greater mastery of the course content (Philipp, Tretter, \& Rich, 2016), and show positive impact on overall student engagement and retention in students with underdeveloped basic-academic skills (Callahan, 2009; Peck, 2011; Flores \& Duran, 2013). 
Furthermore, peer tutoring is more cost-effective compared to faculty or staff tutoring and more educationally effective as it allows the learner to seek academic assistance from a similar-age peer, which is less threatening to the learner's selfesteem compared to seeking help from authority figures (Gross \& McMullen, 1983). The peer teacher and learner often have more similar amounts of prior experience with the concept being learned and closer in stage of cognitive development, both of which serve to facilitate learning (Vygotsky, 1978).

\section{Peer Mentoring}

The peer-support strategy, in practice, has a more holistic and intrusive focus than peer tutoring, whereby the peer mentor provides social, emotional and academic support to the mentee. Also, mentor-protégé contacts occur in a wider range of educational and social contexts than the tutor-tutee contacts. Typically, peer-mentoring programs involves pairing more experienced students, usually juniors or seniors that serve as mentors for less experienced students usually freshmen or sophomores, for the twofold purpose to promote the educational success of the protégé and nurture the leadership or counseling skills of the peer mentor. The effectiveness of peer mentoring is supported by cross-institutional research that showed students who participated in such programs displayed higher rates of retention and academic achievement (as measured by grade-point average) than non-participating students with comparable college-entry characteristics (Lane, 2018; Graham \& McClain, 2019).

\section{Peer Study Groups}

This academic-support strategy is defined broadly and characterized by students meeting in small groups outside of class time to support each others' study, and master course materials and contents. These peer-study groups evolve spontaneously among students with common interests, or deliberately setup and promoted by instructors and academicsupport professionals. The term "study group" range from a group of students that come together for review sessions in preparation for exams or formed to achieve additional learning tasks that include note-taking mastery groups, reading groups, library research group to test-results review groups.

The positive impact of collaborative and peer study groups on retention and achievement of first-to-second year students is supported by research that showed increased five-year retention rates for participants in collaborative learning workshops that was 25\% higher (Treisman, 1992) and 36\% higher in another five-year longitudinal study (Bonsangue, 1993). Also, the long term effect of peer learning program showed strong positive correlation with first-year students' achievement, retention, and degree attainment (van der Meer, Wass, Scott, \& Kokaua, 2017).

\section{Cooperative Learning Groups}

Cooperative learning groups (CLG) is characterized by the distinctive features of small, intentionally formed groups, with well-defined roles for all group members, structured group work to safeguard that members work interdependently on the same learning task to produce a unified product, structured group work for members personal accountability for their individual contributions to the final product, and an instructor's role to facilitate with sub-groups during the learning process. Cooperative learning is intentionally structured so the small-group learning process magnifies its collaborative impact and that each group member understand clearly their individual roles and contributions to the larger project. The CLG model can in used in combination with other group-learning program (for example, with small-group tutoring, supplemental instruction, or learning communities). CLG is well-documented to enhance students' performances on multiple outcomes, including academic achievement, social development, and self-esteem persistence - all of these indices are crucial and important contributions to retention of first-year students (Yamarik, 2007). Additionally, more comprehensive supportive evidence of the educational impact of cooperative learning is provided by a large meta-analysis of its effects on college students' academic performance in science, math, engineering and technology (National Institute for Science Education, 1984) that demonstrated cooperative learning positively impact academic achievements, student retention, and "liking attitude" of specific subject matter - particularly in areas with difficult to understand concepts such as mathematics, philosophy and other abstract courses. Therefore, key features of cooperative learning can be intentionally implemented using a variety of structured cooperative-learning procedures that is useful in a variety of curricular areas and learning contexts (Esmonde, 2017), or as essentially content-free procedures for a variety of purposes (Rosol, 2012).

\section{Supplemental Instruction (SI)}

The SI target students population with high dropout or failure rates in introductory and foundational "gateway" courses for first- or second-year students are targeted and particularly suited for this peer teaching-learning strategy (Dawson, Van der Meer, Skalicky, \& Cowley, 2014; Tinto, 2012). This academic-support program involves pairing students that performed exceptionally well in a particular course that are then compensated to re-attend the same class along with novice learners, and help the novices individually and in group sessions. The student leader purpose as a model learner takes and compares notes, complete assignments and tests with the novice. The "supplemental" out-of-class sessions are 
typically conducted as informal seminars during when students compare notes, discuss reading assignments, predict test questions, and study collaboratively. More recently, video-based supplemental instruction (VSI) has been adapted as an alternative to SI. The VSI interactive information processing and delivery system help academically at-risk students master rigorous course content as they simultaneously develop and refine reasoning and learning skills. Research data on effectiveness of VSI is shown to increase effectiveness of learning, (Kerr, \& Schlueter, et al, 2017) and a superior mode of learning compared to other teaching methods (Beisingel, Mitchell \& Hill, 2017). The effectiveness of VSI is attributed to its power of peers teaching or tutoring peers, integration of academic skills instruction into a meaningful credit-earning, content-specific course, eliminates the stigma often associated with "developmental" or "remedial" connotation, and it enables initially less-prepared students to gain access to and receive supplemental support in academically demanding courses, without lowering course instructors' academic standards (Drake 2011; Institute for Education Science,2013).

\section{Learning Communities (LCs)}

All models of learning communities (LCs) share distinguishing features of co-registration of a cohort of students, who take the same block of courses. While a common theme for all models of learning-community, variations occur in the number of courses students take together during the term - which range from two to an entire course load of 4-5 courses, whether the cohort consist of an entire class or a subset of a larger class, or some combination thereof. For example, a cohort may comprise of the entire enrollment of a small General Science or English class that co-enroll in a history course with a larger class size. Empirical support for the educational effectiveness of LCs programs showed students became more actively involved in classroom learning, reported greater intellectual gains, tended to form their own support groups that extend beyond the classroom, spent more time together outside of class, and displayed high rates of retention (Thomas, Walsh, Torr, Alvarez, Malagon, 2018; Johnson, 2000).

LCs may take the form of an umbrella of program, embracing a variety of different curricular structures within which are nested two major forms of collaboration: collaboration between students, and collaboration between faculty. Collaboration between students learning-community models include "Course Linking" or "Course Pairing" where a cohort of students co-registers for the same pair of courses, which they take concurrently during the same academic terms. These forms of LCs create a sense of community among students without isolating them from other students outside the cohort, and without negating their potentially positive influence on other students. Another LCs collaboration between students is the Freshman Interest Groups. This is a form of learning cluster designed specifically for first-year students where small cohorts of freshmen (typically between 15 to 25 students) recruited from diverse or similar geographic locations or those that participated in a summer bridge program or from similar background or those that bond during new-student orientation are encouraged or advised to register for the same 3 to 4 courses - which often constitute a related set of general education requirements or pre-major courses in the students' field of academic interest. This cohort of freshmen then attend classes together as a subset of about 20 to 30 students to three or four larger common classes or courses. One of these model typically has a small-class component that involves only the freshman interest group students - including labs or discussion group formed from a course that may have a much larger number of students. The effectiveness of this pairing is supported by data that showed fewer students withdraw from academically competitive courses, and displayed significantly higher grade-point averages than do students taking the same courses but not members of the program (Mlynarczyk \& Babbitt, 2002).

\section{Collaboration Between Academic Support Services and Instructional Faculty}

Academic support programs are more effectively delivered and received by students when integrated with college course contents and classroom learning (Pelton, 2014; Ouellette, 2010). Research data show that basic academic specific subject matter skills are most effectively learned and contextualized (Mehta, Newbold, \& O'Rourke, 2011). Therefore, students need to have a sense of purpose for using these skills for effective learning and knowledge to be ingrained and become fully incorporated into their habitual approach to learning. Research on human brain and learning processes further reinforces this important integration learning-skill development with classroom-based learning which distinguish the difference between "declarative" knowledge — knowing what to do, as opposed to "procedural" knowledge — knowing how, when, and where to implement or apply that knowledge (Squire, 1986).

\section{Early-Alert or Early-Warning System}

This academic support strategy is a formal feedback system through which course instructors at or before midterm alert learning assistance professionals and/or academic advisors on students performances and in jeopardy of poor outcomes/grades. A recent survey found over $60 \%$ of institutions report mid-term grades to first-year students for early feedback of their academic performance, and $10 \%$ of these institutions obtained students' right-to-privacy waivers that enable them to report to their parents (Brothen, Wambach \& Madyun, 2003). Students with low mid-term grade reports are notified to meet with academic advisor who, in turn, refers the students for appropriate support services. While issuing mid-term-grade reports to struggling students is a creditable practice, Alley (2002) surmised that, by the time midterm 
grades are recorded and disseminated, the feedback may not be timely for students to take corrective actions. Consequently, some institutions are resorting to an earlier feedback mechanism based on student attendance during the first 4 to 6 weeks of the semester/term.

Evidence for the positive impact of an early-alert system on student retention has been provided where after the third of week of the semester, early-alert notifications were sent from instructors teaching preparatory and basic-skill courses populated for identified "high-risk" students were referred to support services that initiated intrusive intervention through meetings with each student, academic interventional counseling, and referral to a peer tutor program. Since the early-alert program was initiated, retention rates for at-risk students have risen steadily to over 70 percent positive outcomes and persistence through this vulnerable first-year (Green, 1989).

Another variant of the early-warning system described by Espinoza \& Genna (2018) used individualized learning analytics and early performance feedback over 2 years in multiple courses, and with different instructors that identified at-risk students and provided referrals to academic support services. Findings from this showed that high-risk college students benefitted with higher achievement (GPAs) and persistence.

In addition to the early-alert or early-warning systems, course-integration strategies also present an approach that ensure close collaboration between classroom faculty and academic-support service professionals that better serve the needs of first-year students. The course-integration system takes various forms including where faculty provide specific information about the academic requirements of their courses to learning assistance professionals to enhance the relevance and effectiveness of academic support and tutorial services. For example, instructors provide a sample of reading assignments or lecture videotapes for tutorial use in the college Learning Center or when learning assistance professionals visit "at-risk courses" (courses with high rates of student withdrawal and low grades) to describe how their services contribute to student success in the course, and encourage students to benefit from these services. Another variant is where instructors purposefully design class assignments that partners and encourage students with learning assistance professionals.

\section{Partnerships Between Students' Affairs and Academic Departments}

Gaps between student and academic affairs remains prevalent in many higher education. These campus chasm and compartmentalization hinder student holistic development and success, and makes it difficult for students to achieve and make crucial connections between academic and co-curriculum experiences (Kuh \& Banta, 2000). These fragmented components are required to join forces if collegiate institutions intend to promote productive partnerships that enhance student retention, persistence, maximize student learning, advance institutional assessment, and quality to fulfill the overarching collegiate goals of education and holistic development, and build a campus community (Martinez, 2017; Kuh, \& Banta, 2000).

\section{Integration of New-Student Orientation and Academic Convocation}

Convocation, in its simplest form is a formal gathering of faculty, administrative and support services members from the college community that congregate for the purposes to welcome, recognize, celebrate, and initiate the freshman class into the college. Convocation can serve as the initial component of new-student orientation is consistent with the principle of "front loading" which reallocate and redistribute institutional resources to the forward-facing period of the college experience (Davig \& Spain, 2003), and a community-building ritual that promotes student identification with the institution (Kuh, Schuh, Whitt, \& Associates, 1991; Mayhew, Vanderlinden \& Kim 2010). Academic convocation represent a meaningful rite of passage that elevate students' sense of belonging and incorporation into the college community (Tinto, 1993). Additionally, it assist to make new students feel less marginalized and more significant and that they "matter" (Schlossberg, Lynch, \& Chickering, 1989), and an important validation experience - especially for first-generation students (Rendon, 1994) which can assist students visualize and set self-goals to graduation (Light, 2001).

\section{Living-Learning Centers}

Post-secondary institutions that have a structured and managed on-campus living arrangements (dormitories) have taken advantage of living-learning centers and introduced residentially based educational programs that combine academic and student affairs programs designed for first-year students. For example, academic advising and learning assistance services is provided in student residences, or seminar-style classes taught in residence lounges. At some large universities, livinglearning centers are designed to provide a more friendly "small-college" atmosphere, while at smaller colleges these centers are organized around different learning themes, such as wellness, diversity issues, academic self-regulation (Schein \& Bowers, 1992). Orientation courses and living-learning communities is shown to boost academic retention and graduation via enhanced self-efficacy and self-regulated learning (Cambridge-Williams, Winsler, Kitsantas \& Bernard, 2013), promote sense of belonging and participation - even at the academic departmental and class levels (Knekta \& McCartney, 2018). Another variant of this model is the Residential Learning Communities designed to include a 
residential-life component where students registered in the same courses share the same living space on campus. This arrangement is shown to enhance adjustments to the college environment, increase persistence, students engagement and retention (Levine \& Tompkins, 1996).

\section{First-Year Experience Seminars and Extended-Orientation Courses}

First-year seminar (FYSs) is a diverse instructional concept with common goal aimed to improve student retention rates. Research supported by empirical data show a positive and statistically significant relationship between seminar participation, college achievement, and higher persistence rates which has led to the adoption and proliferation of the FYSs (Vahe \& Credé, 2016). These orientation or first-year experience courses are collaborative endeavors between the academic and students affairs units that ensures beginning students receive the holistic support they need to survive and thrive during the critical first year of college. The content of first-year experience seminars typically include components or all topics designed to understanding the purpose, values, and expectation of higher education, learning academic-skills development, learning strategies, critical thinking skills, self and time -management, self-assessment and self-awareness, and learning styles, life planning skills that connect the current academic experience to future personal and vocational goals, and holistic development for social, emotional, and physical wellness.

The most recurrent assessed outcome of the first-year seminar is its impact on student retention. The positive impact of these seminars, has been substantiated by quantitative and qualitative, experimental and correlational analysis that show positive impact of the course on students outcome measures in at-risk, well-prepared, minority and majority, residential and commuter students at 2- and 4-year and in public and private, various institutional sizes, and institutional locations. Vahe \& Credé, (2016) noted, that first-year/student success seminars are creative and adaptable courses to a large variety of institutional settings, structures, and students types. Direct evidence for the positive impact of first-year seminars on students' academic performance and retention has been shown in students surveys (Barefoot, 2001; Burgette \& MagunJackson, 2009), to enhance both short and long term impact - first-term grade point average, persistence (Swanson, Vaughan, \& Wilkinson, 2015), and foster higher retention and graduation in a discrete-time survival analyses (Miller \& Lesik, 2014). Additionally, extended new-student orientation into full-semester courses has been shown to provide adequate time for coverage of a wide range of topics critical to effective college adjustment and student success (Clark \& Cundiff, 2011;Williford, Chapman \& Kahrig, 2001), and for timely discussions and addressing college adjustment issues as they arise during the critical year when discontinuation is likely to occur. Another salient example of these extended courses is the coverage of test-taking strategies which can be purposely scheduled to occur prior to major class tests, midterm, end of semester exams when students immediately apply these strategies and then followed by discussions of the effectiveness of the interventional strategies after receipt of the test results. These timely class discussions and adjustment solution strategies, at or around the time students experience them during their first term of college offers instantaneous relevance and practicality of course information, thus increasing their motivation to attend and put into practice the strategies taught during the FYE course (Reid, Reynolds \& Perkins-Auman, 2014; Rogerson, \& Poock, 2013). Additionally, these orientation when extended into a full-length course provide abundant opportunities for peer bonding and forum for providing social and emotional support that develops among classmates as they interact frequently in a social context devoted to the student-centered topics of college adjustment and success (Hold \& Fifer, 2016; Ang, Lee \& Dipolog-Ubanan, 2019; Lane, 2018).These extension and integrated programs is available to administrators to promote awareness and knowledge of campus programs and out-of-class support, increases student use of college resources and services (Barefoot \& Fidler, 1996), and useful for early identification and early alert of first-term students that are academically "at-risk" (Klatt \& Ray, 2014).

\section{Summer Bridge Programs}

This form of academic-support, social integration typically is delivered to students during the summer following high school and in their first term in college, and thus a "bridge" between high school and post-secondary education. Summer bridge programs generally target academically "at-risk," underprepared students population and programmed to include academic skills assessment and instructions, orientation to the social and academic curriculum of higher education, and a residential experience whereby participants take courses together. Educational institutions incorporate this innovative alternative approaches as part of developmental education to accelerate students' progress in important academic competencies and academic self-efficacy (Martin, Goldwasser \& Harris, 2015; Grace-Odeleye \& Santiago, 2019). Additionally, bridge programs offer under-prepared and at-risk students the opportunity to progress toward college-level coursework during the summer before they begin college.

Summer bridge programs are increasingly popular strategy that provides students with the knowledge and skills required for success in college, advising, and career selection support. The distinguishing characteristics of summer-bridge is the programmatic approaches and resources developed to address issue including general education freshman courses in reading, writing, peer counseling programs, upper class students and faculty mentorship, all of which provide at-risk 
students the academic preparation, and social support for integration into the college community. These support structures are designed to support college students succeed with the introduction to campuses services, taking actual credited courses, and provision of peer advisors and mentors, faculty, and staff support system in place before and during the school year.

\section{Conclusions and Final Reflections}

What would it mean for institutions to take student retention - particularly during the vulnerable years, seriously? Among other things, institutions should stop fiddling at the margins of institutional academic life and make enhancing student retention the linchpin about which they organize their activities and transcend beyond the provision of add-on services and establish those integrative educational and social support conditions on campus that promote students' retention. Institutions should recognize that the roots of attrition is a product of the students and the academic and social situations they face, and in the very character of the educational settings in which students learn.

A reflective analysis of the most successful academic-support programs, supported by empirical data show recurring features that are core principles of effective program delivery of academic-support services to first-year students. These key features, summarized below serve as the conclusion of this review.

\section{Effective First-Year Support Programs are Intentionally Student-Centered}

Powerful first-year programs are oriented toward, focused on, and driven by the intentional goal of promoting student success. Effective programs often involve creative and intentional rearrangement of traditional services delivery systems to center them squarely on the goal of promoting students' academic success and retention. For example, learning community programs promote student learning by capitalizing on the proven power of peer collaboration. Similarly, the cooperative learning structures achieve the same objectives through reorganization of the classroom and transforming it from its traditional format of one large group of individuals working independently into interdependent and collaborative smaller teams of peer learners.

\section{Effective First-Year Support Programs are Intrusive}

Most effective programs that enhance students engagements, increase persistence and retention are those that initiate proactive supportive programs by reaching out to students or delivered support to them, rather than passively waiting and hoping that first-year students seek it out on their own. Both student effort and institutional effort are required to promote students' success, but very short attention has been paid to the latter form of effort in the higher education literature. Effective programming for first-year students is characterized by a high degree of institutional initiatives and expenditure of substantial institutional effort to ensure that programmatic support reaches all students who are likely to profit from it. Effective support programs cited in this review implement the principle of intrusiveness and engaged in practices as delivering support services to students on their "turf" (for example, through living learning centers and residential learning communities), and infusion of support services directly into the classroom.

\section{Effective First-Year Support Programs are Proactive}

Effective program delivery is characterized by early, preventative action that addresses students' needs and adjustment issues in anticipatory fashion - before they eventuate in full-blown problems that required reactive intervention. Proactive program delivery ensures that support reaches students at the time, they need it the most when they are most vulnerable to academic failure and attrition and when support is most likely to have its greatest long-term impact on students. "Front loading" has become an almost self-evident principle of effective undergraduate education, and many of the successful programs described in this review successfully implemented this principle, including: (a) summer bridge programs, (b) early-alert systems, (c) programs that merged new-student orientation with academic convocation, and (d) first-year experience courses.

\section{Effective First-Year Support Programs are Collaborative}

Effective student-support programs involved cooperative alliances between different members and organizational units of the college which work together in an integrated, interdependent, and symbiotic fashion to provide comprehensive, holistic support for first-year students. Successful support programs are distinguished by the presence of cross functional collaborative relationships, such as those between (a) faculty and academic-support specialists - that implemented effective early alert systems and course-integrated learning assistance programs; (b) academic and student affairs professionals to implement jointly conducted orientation-and-convocation programs and living/learning centers, and (c) colleges and schools to coordinate summer bridge and school outreach programs.

Perhaps one of the most important benefits of collaborative programs is that they serve to foster the development of a culture of collaboration on campus. Research in higher education reveals that campus cultures which are identified as collaborative, rather than competitive or individualistic, are characterized by a higher level of faculty and staff 
participation and a greater sense of perceived "community" among its members. This positive by-product of collaborative programming on faculty and staff in itself serve to promote the retention and success of first-year students on campus.

\section{Effective First-Year Support Programs are Diversified:}

Effective programming are customized to meet the distinctive needs of students from different subpopulations, and the needs of students at different stages of their college experience. Diversified program delivery recognizes the reality that the undergraduate student body is comprised of different subgroups and subcultures whose needs vary, depending on their background experiences prior to college and their level of experience with college. Diversified programming acknowledges students' unique characteristics and addresses the developmental challenges they experience at different stages of the college experience (for instance first year vs. final year). No single response meets the needs of all students. Additionally, effective program is responsive to differences among learners and displays programmatic flexibility.

\section{Effective First-Year Support Programs are Centralized:}

Effective programming takes a central place in the college's organizational structure or system, giving it the capacity to exert a pervasive and systemic effect on the students' total college experience. These programs are not marginalized and relegated to peripheral status as a "add-on." Rather, these programs are woven integrally into the university's organizational design and annual budgetary allotment. When situated centrally and deeply within the institution's structure, these program becomes institutionalized ensuring its stability and durability.

\section{Effective First-Year Support Programs Set Clear Goals to Students and Provide Timely Feedbacks:}

Students are more likely to persist and graduate in settings that hold high and clear expectations for student achievements. students do best in settings where expectations are clear and consistent. This is particular evident in the domain of academic advising. Students need clarity on expectations and the pathways for successful completion of a degree program of study. Students, especially the many who are undecided about their plans, need to understand the road map to completion and know how to use it to achieve personal goals. Secondly, feedback is a condition for student success. Students are more likely to succeed in settings that provide faculty, staff, and students frequent feedback about their performance. This include entry assessment of learning skills, early warning systems that alert institutions to students who need assistance, and classroom assessment techniques.

\section{Effective First-Year Support Programs Integrate Academic and Social Engagement:}

Academic and social integration and engagement is critical to student retention. The more students are academically and socially involved, the more likely are they to persist and graduate. Simply put, involvement and engagement matters

\section{References}

ACT, Inc. (2005). Crisis at the core: Preparing all students for college and work. Retrieved from https://eric.ed.gov/?id=ED493181

Alley, V. (2002). Midterm grade reports: Are they effective? Research and Teaching in Developmental Education, 19, 1424.

Altermatt, E. R. (2016). Academic support from peers as a predictor of academic self-efficacy among college students. Journal of College Student Retention: Research, Theory \& Practice, 21, 21-37. https://doi.org/10.1177/1521025116686588

American Institutes of Research, (2011). New study reveals the annual costs of dropouts from one freshman class - Both to themselves and society, August 2011. Retrieved from https://www.air.org/sites/default/files/downloads/report/AIR_High_Cost_of_Low_Graduation_Aug2011_0.pdf

Ang, C., Lee, K., \& Dipolog-Ubanan, G. F. (2019). Determinants of first-year student identity and satisfaction in higher education: a quantitative case study. SAGE Open, 9, 2. Retrieved from https://doi.org/10.1177/2158244019846689

Backer, L., Van Keer, H., \& Valcke, M. (2012). Exploring the potential impact of reciprocal peer tutoring on higher education students' metacognitive knowledge and regulation. Instructional Science, 40, 559-588. https://doi.org/10.1007/s11251-011-9190-5

Barefoot, B. O. (2000). The first-year experience: Are we making it any better? About Campus, 4, 12-18. https://doi.org/10.1177/108648220000400604

Barefoot, B. O., \& Fidler, P. P. (1992). Helping first-year students climb the academic ladder: 1991 national survey of freshman seminar programming (Monograph Series No. 10). Columbia, SC: University of South Carolina, National 
Resource Center for the Freshman Year Experience.

Beisingel, M., Mitchell, R., \& Hill, H. C. (2017). The Design of Video-Based Professional Development: An Exploratory Experiment Intended to Identify Effective Features. Journal of Teacher Education, 69, 69-89. https://doi.org/10.1177/0022487117705096

Benware, C. A., \& Deci, E. L. (1984). Quality of learning with an active versus passive motivational set. American Educational Research Journal, 21, 755-765. https://doi.org/10.2307/1162999

Bonsangue, M. V. (1993). The effects of calculus workshop groups on minority achievement in mathematics, science, and engineering. Cooperative Learning and College Teaching, 3, 8-9.

Branch, K., Hart-Steffes, J., \& Wilson, C. (2019). (Eds). Applying student development theories holistically: exemplar programming in higher education. Routledge Taylor and Francis Group, New York, NY. https://doi.org/10.4324/9781351212311

Brothen, T., Wambach, C., \& Madyun, N. (2003). Early Alerts II: An Experimental Evaluation. Research and Teaching in Developmental Education, 20, 22-28.

Burgette, J., \& Magun-Jackson, S. (2009). Freshman orientation, persistence, and achievement: A longitudinal analysis. Journal of College Retention: Research, Theory and Practice, 10, 235-263. https://doi.org/10.2190/CS.10.3.a

Burton, L. J., Chester, A., Xenos, S., \& Elgar, K. (2013). Peer mentoring to develop psychological literacy in first-year and graduating students. Psychology Learning \& Teaching, 12, 136.

Callahan, K. M. (2009). Academic-centered peer interactions and retention in undergraduate. Mathematics Programs, 10, 361-389. https://doi.org/10.2190/CS.10.3.f

Cambridge-Williams, T., Winsler, A., Kitsantas, A., \& Bernard, E. (2013). University 100 Orientation Courses and LivingLearning Communities Boost academic retention and graduation via enhanced self-efficacy and self-regulated learning. Journal of College Student Retention: Research, Theory \& Practice, 15, 243-268.

Casselman, B. (2012). The Cost of Dropping Out. Millions Struggle With High College Debt and No Degree. The Wall Street Journal, 22. Retrieved from https://www.wsj.com/articles/SB10001424127887324595904578117400943472068\#

Chickering, A. W., Lynch, A. Q., \& Schlossberg, N. K. (1989). Improving higher education environments for adults.

Clark, M. H., \& Cundiff, N. L. (2011). Assessing the effectiveness of a college freshman seminar using propensitys score adjustments. Research in Higher Education, 52, 616-638. https://doi.org/10.1007/s11162-010-9208-x

College, Board. (2009). How colleges organize themselves to increase student persistence: Four year institutions. Retrieved from http://pas.indiana.edu/pdf/How\%20Colleges\%20Organize.pdf

Cottam, J., Menzel, S., \& Greenblatt, J. (2011). Tutoring for retention. SIGCSE'11-Proceedings of the 42nd ACM Technical Symposium on Computer Science Education. Retrieved from https://doi.org/10.1145/1953163.1953227

Davig, W. B., \& Spain, J. W. (2003). Impact on freshmen retention of orientation course content: proposed persistence model. Journal of College Student Retention: Research, Theory \& Practice, 5, 305-323. https://doi.org/10.2190/V6B4-PQAW-TTV0-CJCU

Dawson, P., Van der Meer, J., Skalicky, J., \& Cowley, K. (2014). On the Effectiveness of Supplemental Instruction: A Systematic Review of Supplemental Instruction and Peer-Assisted Study Sessions Literature Between 2001 and 2010. Review of Educational Research, 84(4), 609-639.

Deangelo, L. (2014). Programs and practices that retain students from the first to second year: Results from a national study. New Directions for Institutional Research. 2013: 53-75. doi: 10.1002/ir.20061 Drake, J. K. (2011a). The Role of Academic Advising in Student Retention and Persistence. About Campus, 16, 8-12. https://doi.org/10.1002/abc.20062

Drake, R. (2011). Why Should Faculty Be Involved in Supplemental Instruction. College Teaching, 59, 135-141. https://doi.org/10.1080/87567555.2011.586656

Engel, J. (2015). Answering the Call: Institutions and States Lead the Way Toward Better Measures of Postsecondary Performance. Seattle, WA: Bill \& Melinda Gates Foundation.

Esmonde, I. (2017). Ideas and identities: Supporting equity in cooperative mathematics learning. Review of Educational Research, 79, 1008 -1043.

Espinoza, E., \& Genna, G. M. (2018). Hi, I want to talk to you about your progress: A large course Intervention for at- 
risk college students. Journal of College Student Retention: Research, Theory \& Practice, July 2018. Retrieved from https://doi.org/10.1177/1521025118790054

Flores, M., \& Duran, D. (2013). Effects of peer tutoring on reading self-concept. International Journal of Educational Psychology, 2, 297-324.

Gershenfeld, S., Hood, D. W., \& Zhan, M. (2016). The role of first-semester GPA in predicting graduation rates of underrepresented students. Journal of College Student Retention: Research, Theory \& Practice, 17, 469-488.

Grace-Odeleye, B. (2015). Does remediation work? Developing a summer program for first-year students. 26th Annual Conference for Teaching Academic Survival and Success, Fort Lauderdale, March 2015

Grace-Odeleye, B., \& Cadebolt, K. (2018). A new paradigm: A high-impact first-year student program. 37th Annual Conference of the First-Year Experience. San Antonio, TX, February 2018

Grace-Odeleye, B., \& Santiago, J. (2019). An examination of cross-sectional summer bridge programs for first-generation at risk students. Administrative Issue Journal: Connecting Education, Practice, and Research, 9, 35-47.

Graham, J., \& McClain, S. (2019). A canonical correlational analysis examining the relationship between peer mentorship, belongingness, impostor feelings, and black collegians' academic and psychosocial outcomes. American Educational Research Journal, 56. Retrieved from https://doi.org/10.3102/0002831219842571

Grave, B. S. (2011). The effect of student time allocation on academic achievement. Education Economics, 19, 291-310. https://doi.org/10.2139/ssrn.1753646

Green, S. (1994). Graduation rates double for underprepared students at Indiana University at Kokomo. The Freshman Year Experience Newsletter, 7, 4.

Greenfield, G. M., Keup, J. R., \& Gardner, J. N. (2013). Developing and sustaining successful first-year programs: A guide for practitioners. San Francisco, CA: Jossey Bass

Gross, A. E., \& McMullen, P. A. (1983). Models of help-seeking process. In F. D. Fisher, A. https://doi.org/10.1016/B9780-12-210820-4.50018-6

Haktanir, A., Watson, J. C., Ermis-Demirtas, H., Karaman, M. E. Freeman, P., Kumaran, D., \& Streeter, A. (2018). Resilience, academic self-concept, and college adjustment among first-year students. Journal of College Student Retention: Research, Theory \& Practice, Nov 2018. Retrieved from https://doi.org/10.1177/1521025118810666

Hammond, J. A., Bithel, C. P., Jones, L., \& Bidgood, P. (2010). A first year experience of student-directed peer-assisted learning. Active Learning in Higher Education, 11, 201-212. https://doi.org/10.1177/1469787410379683

Havlik, S., Pulliam, N., Malott, K., \& Steen, S. (2017). Strengths and struggles: First-generation college-goers persisting at one predominantly white institution. Journal of College Student Retention: Research, Theory \& Practice. Retrieved from https://doi.org/10.1177/1521025117724551

Ho, Y. (2006). The impact of interaction with peers on college student development. The Journal of Human Resource and Adult Learning, 12, 81-87.

Hold, L. J., \& Fifer, J. E. (2016). Peer mentor characteristics that predict supportive relationships with first-year students: Implications for peer mentor programming and first-year student retention. Journal of College Student Retention: Research, Theory \& Practice, 18, 167-191.

Institute for Education Science. National Center for Education Statistics (2013). First-Year Undergraduate Remedial Course taking: 1999-2000, 2003-04, 2007-08. Retrieved from https://nces.ed.gov/pubs2013/2013013.pdf

Johnson, J. L. (2000). Learning communities and special efforts in the retention of university students: what works, what doesn't, and is the return worth the investment? Journal of College Student Retention: Research, Theory \& Practice, 2, 219-238. https://doi.org/10.2190/V0PA-BL4B-1X2L-W5VT

Kerr, H. A., Ledet, E. H., Ata, A., Newitt, J. L, Barbara, M. S., Kahanda, M., \& Schlueter, E. (2017). Does instructional video footage improve tackle technique? International Journal of Sports Science \& Coaching, 13, 3-15. https://doi.org/10.1177/1747954117711867

Kim, E., Newton, F. B., Downey, R. G., \& Benton, S. L. (2010). Personal factors impacting college student success: Constructing college learning effectiveness inventory (CLEI). College Student Journal, 44, 112-125.

Kim, J., Lim, D. H., \& Stewart, S. (2015). Factors influencing college persistence for first-time students. Journal of Developmental Education, 38, 12-20.

Kim, Y. K. \& Sax, L.J. (2017). The Impact of College Students' Interactions with Faculty: A Review of General and 
Conditional Effects, Higher Education: Handbook of Theory and Research, 3, 85-139.

Kiyama, J. M., \& Luca, S. G. (2016). Structured Opportunities: Exploring the Social and Academic Benefits for Peer Mentors in Retention Programs. Journal of College Student Retention: Research, Theory \& Practice, 15, $489-514$.

Klatt, J., \& Ray, R., (2014). Student Academic Outcomes after Completing a First-Year Seminar NACTA Journal, 58, 288-292.

Knekta, E., \& McCartney, M. (2018). What Can Departments Do to Increase Students' Retention? A Case Study of Students' Sense of Belonging and Involvement in a Biology Department. Journal of College Student Retention: Research, Theory \& Practice. Retrieved from https://doi.org/10.1177/1521025118788351

Kuh, G. D., \& Banta, T. W. (2000). Faculty-student affairs collaboration on assessment: Lessons from the field. About Campus, 4, 4-11. https://doi.org/10.1177/108648220000400603

Kuh, G. D., Schuh, J., Whitt, E., \& Associates (1991). Involving colleges: Encouraging student learning and personal development through out-of-class experiences. San Francisco: Jossey-Bass.

Lane, R. (2018). Addressing the stressful first year in college: could peer mentoring be a critical strategy? Journal of College Student Retention: Research, Theory \& Practice, retrieved from https://doi.org/10.1177/1521025118773319

Levine, J. H., \& Tompkins, D. P. (1996). Making learning communities work: Seven lessons from Temple University. AAHE Bulletin, 48, 3-6.

Levitz, R., Noel, L., \& Richter, B. (1999). Strategic Moves for Retention Success. New Directions for Higher Education, 108, 31-49. https://doi.org/10.1002/he.10803

Light, A. (2001). Report on findings from the 2001 undergraduate student support Survey. Retrieved from https:/www.ucop.edu/student-affairs/_files/undergradsupport_surveyrpt2001.pdf

MacGregor, J. (1991). What differences do learning communities make? Washington Center News, 6, 4-9.

MacGregor, J. (2000). Restructuring large classes to create communities of learners. New Directions for Teaching \& Learning, 81, 47-61.

MacGregor, J., Cooper, J. L., Smith, K. A., \& Robinson, P. (2000). Strategies for Energizing Large Classes: From Small Groups to Learning Communities. The Jossey-Bass Higher and Adult Education Series. Jossey-Bass Inc., Publishers, 350 Sansome Street, San Francisco, CA 94104-1342.

Martin, D., \& Blanc, R. (2001). Video-based supplemental instruction (VSI). Journal of Developmental Education, 24, $12-45$.

Martin, K., Goldwasser, M., \& Harris, E. (2015). Developmental education's impact on students' academic self-concept and self-efficacy. Journal of College Student Retention: Research, Theory \& Practice, 18, 401-414.

Martinez, E. (2017). Changes, challenges, and opportunities for student services at one baccalaureate degree-granting community college. Community College Review, 46, 82-103. https://doi.org/10.1177/0091552117744049

Mayhew, M., Vanderlinden, K., \& Kim, E. (2010). A Multi-level assessment of the impact of orientation programs on student learning. Research in Higher Education, 51, 320-345.

Mazlan, I., Aziz, F. H., Mohamed, F. A. B., Ismail, M. F., \& Shah, A. P. (2017). The relationship between self - efficacy and GPA grade scores of students. International Journal of Applied Psychology, 7, 44-47.

McFarland, J., Hussar, B., Wang, X., Zhang, J., Wang, K., Rathbun, A., ... Bullock Mann, F. (2018). The Condition of Education 2018 (NCES 2018-144).

Mehta, S. S., Newbold, J. J., \& O'Rourke, M. A. (2011). Why do first-generation students fail? College Student Journal, 45,1 .

Mellado, M. E., Valdebenito, V., \& Aravena, O. (2017). Peer Tutoring to develop social skills among University Students. International Journal of Pedagogies \& Learning, 12(2), 147-159.

Miller, J. W., \& Lesik, S. S. (2014). College persistence over time and participation in a first-year seminar. Journal of College Student Retention: Research, Theory \& Practice, 16, 373-390. https://doi.org/10.2190/CS.16.3.d

Miller, T. K., \& Prince, J. S. (1976). The future of student affairs. San Francisco: Jossey-Bass.

Mlynarczyk, R., \& Babbitt, M. (2002). The power of academic learning communities. Journal of Basic Writing, 21(1), 71-89.

Naples, \& B. M. DePaul (Eds.), New Directions in Helping and Help-Seeking, Volume 2. New York: Academic Press. 
National Center for Education Statistics (2018). Undergraduate retention and graduation rates. May. Retrieved from https://nces.ed.gov/programs/coe/indicator_ctr.asp

National Institute of Education (1984). Involvement in learning: Realizing the potential of American higher education (Report of the NIE Study Group on the Condition of Excellence in American Higher Education). Washington, D.C. U.S. Government Printing Office.

National Student Clearinghouse Center (2018). Completing College. A National View of Student Completion Rates, Dec, 2018. Retrieved from https://nscresearchcenter.org/wp-content/uploads/NSC004_SignatureReport_V9_12DEC18.pdf

Nelson, D., \& Schreiner, L. (2013). he contribution of student satisfaction to persistence. Journal of College Student Retention: Research, Theory \& Practice, 15, 73-111. https://doi.org/10.2190/CS.15.1.f

Noel-Levitz. (2008). Student success, retention, and graduation: Definitions, theories, practices, patterns, and trends. Iowa City, IA: Author.

Oseguera, L., \& Rhee, L. (2009). The influence of institutional retention climates on student persistence to degree completion: A multilevel approach. Research in Higher Education, 50, 546-569.

Ouellette, M. (2010). Student Services in University. In Cox, D. \& Strange, C. (Eds.), Achieving students success: Effective student services in Canadian higher education. Montreal; Kingston; London; Ithaca: McGill-Queen's University Press.

Patton, L. D., Renn, K. A., Guido, F. M., \& Quaye, S. J. (2016). Student development in college: Theory, research, and practice (3rd ed.). San Francisco, CA: Jossey-Bass.

Peck, A. (2011). Peer involvement advisors improve first-year student engagement and retention. About Campus: Enriching the Student Learning Experience, 16, $22-25$.

Pelton, J. A. (2014). How our majors believe they learn: Student learning strategies in an undergraduate theory course. Teaching Sociology, 42, 277-286.

Philipp, S., Tretter, T., \& Rich, C. (2016). Development of undergraduate teaching assistants as effective instructors in STEM courses. Journal of College Science Teaching, 45, 74-82.

Raab, L., \& Adam, A. J. (2005). The university college model: A learning-centered approach to retention and remediation. New Directions for Institutional Research, 125, 87-106.

Reid, K. M., Reynolds, R. E., \& Perkins-Auman, P. G. (2014). College first-year seminars: what are we doing, what should we be doing? Journal of College Student Retention: Research, Theory \& Practice, 16, 73-93.

Rendon, L. I. (1994). Validating culturally diverse students: Toward a new model of learning and student development Innovative Higher Education, 19, 33-51. https://doi.org/10.1007/BF01191156

Rogerson, C. L., \& Poock, M. C. (2013). Differences in Populating First Year Seminars and the Impact on Retention and Course Effectiveness. Journal of College Student Retention: Research, Theory \& Practice, 15, 157-172.

Rosol, S. B. (2012). Adding constructive competition to enhance a cooperative learning experience: a quest for kudos. Journal of Management Education, 37, 562-591.

Roueche, J., \& Roueche, S. (1993). Between a rock and a hard place: The at-risk student in the open-door college. Washington, D.C.: American Association of Community Colleges.

Schein, H. K., \& Bowers, P. M. (1992). Using living/learning centers to provide integrated campus services for freshmen. Journal of The Freshman Year Experience, 4, 59-77.

Squire, L. (1986). Mechanism of memory. Science, 232, 1612-1619.

Strahan, S., \& Crede, M. (2015). Satisfaction with college: Re-examining its structure and its relationships with the intent to remain in college and academic performance. Journal of College Student Retention: Research, Theory \& Practice, $16,537-561$.

Strange, C. C., \& Banning, J. H. (2015). Designing for learning: Creating campus learning environments that work (2nd ed.). San Francisco, CA: Jossey-Bass.

Strayhorn, T. L. (2016). Student development theory in higher education: A social psychological approach [Core Concepts in Higher Education Series]. New York, NY: Routledge.

Swanson, N. M., Vaughan, A. L., \& Wilkinson, B. D. (2015). First-year seminars: Supporting male college students' longterm academic success. Journal of College Student Retention: Research, Theory \& Practice, 18, 386-400. 
Thomas, D. T., Walsh, E. T., Torr, B. M., Alvarez, A. S., \& Malagon, M. C. (2018). Incorporating high-impact practices for retention: A learning community model for transfer students, Journal of College Student Retention: Research, Theory \& Practice. Retrieved from https://doi.org/10.1177/1521025118813618

Tinto, V. (1993). Leaving college: Rethinking the causes and cures of student attrition (2 $2^{\text {nd }}$ ed.). Chicago: University of Chicago Press.

Tinto, V. (2012). Completing college: Rethinking institutional action. Chicago: The University of Chicago Press.

Treisman, U. (1992). Studying students studying calculus: A look at the lives of minority mathematics students in college. College Mathematics Journal, 23, 362-372.

United States Department of Education (2017). Developmental education challenges and strategies for reform. Retrieved from https://www2.ed.gov/about/offices/list/opepd/education-strategies.pdf

Vahe, P., \& Credé, M. (2016). Do first-year seminars improve college grades and retention? A quantitative review of their overall effectiveness and an examination of moderators of effectiveness. Review of Educational Research, 86, 277316.

van der Meer, J., Wass, R., Scott, S., \& Kokaua, J. (2017). Entry characteristics and participation in a peer learning program as predictors of first-year students' achievement, retention, and degree completion. AERA Open, 3, 3. Retrieved from https://doi.org/10.1177/2332858417731572

Vygotsky, L. S. (1978). Internalization of higher cognitive functions. In M. Cole, V. John-Steiner, S. Scribner., \& E. Souberman (Eds. \& Trans.), Mind in society: The development of higher psychological processes (pp. 52-57). Cambridge: Harvard University Press.

Williford, A. M., Chapman, L. C., \& Kahrig. T. (2001). The University Experience Course: A Longitudinal Study of Student Performance, Retention, and Graduation. Journal of Students Retention: Research, Theory and Practice, 2, 327-340.

Wolverton, M., \& Dee, J. (2011). Teaching unprepared students: Strategies for promoting success and retention in higher education: Organizing higher education for collaboration: A guide for campus leaders. Journal of College Student Retention, 12, 379-385.

Woosley, S. A., Sherry, A., \& Shepler, D. K. (2011). Understanding the early integration experiences of first-generation college students. College Student Journal, 45, 20-35.

Yamarik, S. (2007). Does cooperative learning improve student learning outcomes? The Journal of Economic Education, $38,259-277$.

Zhang, X., Gossett, C., Simpson, J., \& Davis, R. (2017). Advising students for success in higher education: An all-out effort. Journal of College Student Retention: Research, Theory \& Practice, 21, 53-77.

\section{Copyrights}

Copyright for this article is retained by the author(s), with first publication rights granted to the journal.

This is an open-access article distributed under the terms and conditions of the Creative Commons Attribution license which permits unrestricted use, distribution, and reproduction in any medium, provided the original work is properly cited. 